\title{
EL OBJETO DE LA PROFESIÓN DEL GUIONISTA
}

Cristian Londoño Proaño Docente dela Universidad Tecnológica Indoamérica. Sede Quito, Ecuador cristianlondono@uti.edu.ec

Recibido: 2 - agosto - 2016 / Aprobado: 3 - octubre - 2016

\section{Resumen}

En el presente texto se discutirá el objeto de la profesión del guionista. Se pondrá a dialogar a distintos autores teóricos del guion y guionistas, considerando que cada vez más, la industria de los medios necesita nuevas historias, y gracias a las nuevas tecnologías, la profesión del guionista ha sufrido cambios.

Palabras clave: guión, guionista, escritor, comunicación, profesiones, cine, televisión.

\begin{abstract}
In the present text the object of the screenwriter's profession will be discussed. Different theoretical authors of the script and scriptwriters will be interviewed considering that increasingly the media industry needs new stories, and thanks to the new technologies, the profession of the scriptwriter has undergone changes.
\end{abstract}

Keywords: script, screenwriter, communication, professions, cinema, television. 


\section{Introducción}

El guionista es un profesional de mucha importancia en la producción de historias para los medios audiovisuales: cine, televisión, los videos en internet, los videojuegos. El volumen de historias que necesita el mercado de la industria audiovisual es cada vez más creciente. Estas historias deben ser escritas por guionistas profesionales. En este ensayo se discutirá sobre el objeto de la profesión de guionista, amparados en las preguntas que plantea Meyers (2010) sobre el modo de descubrir el objeto de una profesión de las comunicaciones. Meyers plantea seis preguntas que responderemos, las que sugiere en la introducción del capítulo "Explanation and a Method for the Ethics of Journalism” de Elliot y Ozar (2010).

\section{¿A quién sirve el guionista? ¿qué bien les procura el guionista?}

Según Seger (1999), el guionista es un escritor, "y un escritor escribe” (p. 15). Pero es un escritor que tiene un campo limitado de acción, ya que es un escritor que escribe guiones o libretos. Estos guiones o libretos tienen descripciones de imágenes y diálogos. En su experiencia, el guionista norteamericano Salt ${ }^{1}$ (1990) señala:

I pray myself someday we are going to recognise screenwriting is in fact a separated form. And what it is, is writing images. There's a separated aesthetic, it's quite different than the theatre or novel. It's a form of writing. And ultima- tely it will be recognize, it will become a very special and wonderful form. Not to compare anyone work to it..., but I think it becomes closer to the technique of poetry rather than technique of film, dramatic writing or novel writing ${ }^{2}$.

En las palabras de Salt se considera que la forma de escribir un guión tiene un juego con la poesía. Mucha poesía explora sentimientos y emociones del propio escritor. Por eso, Salt compara la escritura de guiones con la escritura de poesía.

García-Noblegas (1998) considera al guionista como un explorador de la condición y naturaleza humana. "Algo lejano es al tiempo cercano y lejano, y siempre cargado del suficiente misterio como para provocar la exploración y el descubrimiento de nuevos brillos y nuevos claroscuros" (García-Noblejas, 1998, p. 11). Citemos el caso del guionista norteamericano Salt. "La vida y la obra cinematográfica de Waldo Salt es una continua búsqueda marcada por la exploración. Este hecho es lo que le convierte, aunque él no lo crea, en un artista dentro de su oficio" (Ortiz, 2007, p. 868). Y como todo artista necesita expresar "algo" que subyacente en su interior. Seger (1999) aconseja a los guionistas:

1 Estas palabras fueron recogidas por Paula Ortiz a través de las entrevistas inéditas que recoge el documental sobre su vida y obra Waldo Salt: A Screenwriter's Journey, dirigido por Eugene Corr y Robert Hillmann.

2 Yo me pido a mí mismo que algún día reconozcamos que la escritura de guión es, de hecho, una forma separada. Y lo que es, es escribir en imágenes. Tiene una estética separada, que es bastante diferente de la del teatro o la novela. Es una forma de escritura. Y finalmente será reconocida y llegará a ser una forma especial y maravillosa. Sin comparar el trabajo de nadie, pero yo creo que llegará a ser una forma más próxima a la técnica de la poesía más que a la técnica del cine, la escritura dramática o la escritura de novela (Salt, 1990, trad. Ortiz, P., 2007). 
A pesar de todo, escribes. Lo haces porque tienes algo que decir, porque tienes historias bullendo dentro de ti, personajes que surgen en esas historias y cobran vida propia. Escribes porque tienes ideas que realmente te importan. Escribes porque sientes un fuerte deseo de decir la verdad (p. 15).

Esta "verdad" que señala Seger, se debe entenderla como una "verdad práctica", así lo llamaba Aristóteles. Consideremos que todo guion es una obra poética, y como toda obra poética contiene una "verdad práctica". "La verdad práctica está en relación con la conciencia y con el bien" (García-Noblejas, 2007, p. 2). Llano (2000) señala:

Cuando hablamos de la verdad poética, traducida en bien, se habla de un bien que se atiene estrictamente a la humanidad del hombre, tal como éste es en realidad, y no como podría o debería ser en un marco quizá ideal, pero inexistente (p. 465).

Pero esta verdad poética y la condición de artista del guionista, nos remite al hecho de que el guionista es un artista. Un artista que expresa en su arte una verdad poética, ese sentido del bien que los humanos queremos de nuestra realidad. En este sentido, McKee (2010) señala que el objeto del guionista es narrar historias que busquen los sublime, que sirva de respuesta a la pregunta aristotélica de "¿cómo debería dirigir un ser humano su vida?", que sirva de vehículo, "que nos transporta en nuestra búsqueda de la realidad, nuestro mejor aliado para dar sentido a la anarquía de la existencia" (McKee, 2007, p. 28). Pero este mismo sentido de búsqueda es encontrar la verdad poética, a través de la representación de las necesidades humanas. El guionista norteamericano Walt Salt se esforzaba por reivindicar este punto. Ortiz (2007) señala:

Esta necesidad de reconocer la escritura de guión como búsqueda y representación del drama en imágenes, pensadas y escritas por el guionista, es una reivindicación de su oficio como una forma especial y maravillosa de significar su vocación, sus narraciones y su poética: la representación de las necesidades humanas (p. 889).

El guionista trata de representar las necesidades humanas. Según McKee (2005), los grandes maestros cinematográficos proponen "enfrentarnos a esa doble vertiente que todos ansiamos" (p. 19). La primera vertiente es el descubrimiento de un mundo desconocido. Y la segunda es que en ese mundo desconocido nos encontramos a nosotros mismos, "escondida en las profundidades de esos personajes y sus conflictos hallamos nuestra propia humanidad” (McKee, 2005, p. 19).

\section{¿Cuáles son las relaciones (justas/ideales) entre el guionista y el público?}

Como se discutió en la pregunta anterior, el guionista sirve para expresar una verdad poética. Pero esta verdad poética se vincula al público, lo complace, pero también representa las necesidades humanas. Hay que considerar que el público se relaciona con el guionista, mediante su obra poética (guion), y lo hace de manera di- 
recta en una sala de cine, o cuando mira la televisión, el computador o el dispositivo portátil. En este acto de ver, el público no oculta sus sentimientos cuando mira la obra poética. Por ejemplo, en mitad de una película, puede reír, llorar, gritar, sentir terror, ira, compasión, pasión, amor, odio. Es decir, muchos sentimientos suceden mientras se mira una película y sucede porque es una experiencia vital. McKee (2005) señala:

El público no sólo es inteligente, sino que su inteligencia supera la de la mayoría de las películas, un fenómeno que no cambia cuando uno pasa de pantalla. Lo único que puede hacer un guionista para adelantarse a las agudas percepciones de un público atento es utilizar todas las dotes artísticas que haya adquirido (p. 22).

Es decir, un guionista debe tener como uno más de los factores al público. "El público es un factor tan determinante para el diseño de la historia como cualquier otro elemento" (McKee, 2005, p. 28). Pero no solo es un factor, sino que el guionista, mediante su guion (obra poética), logra establecer una relación cercana con el público. Esta relación es de intercambio. Por una parte, el guionista entrega un guion que contiene una verdad poética, y por el otro, el público recibe la verdad poética y se complace.

\section{¿Cuáles son las relaciones (justas/ideales) entre el guionista y el productor?}

El guionista puede relacionarse con todo el equipo de producción. Tubau (2006) señala que:

Mientras que un novelista sólo tiene que tratar con los editores que estén dispuestos a publicar lo que ha escrito, un guionista está obligado a relacionarse con mucha más gente, tanto si trabaja para el cine como si lo hace para la televisión. Directores, productores, realizadores, editores, actores y cualquier persona que trabaje en la empresa y tenga alguna relación con el guion que está escribiendo (p. 544).

Pero, la primera persona con la que el guionista establece una relación es el productor. Una vez concluido el guion, el guionista busca un productor o una casa productora que ponga en la pantalla (cine, televisión o Internet) su obra. Douglas (2007) aconseja que el guionista debe indagar cuáles productoras aceptan proyectos y enviarles una copia del guion. El productor responde y le invita a realizar una presentación del guion (pitch). Este es el primer momento de la relación con el productor. Douglas (2007) aconseja que en esa reunión debe encantar al productor ejecutivo.

En el caso en que el pitch resulte positivo, el productor establece el segundo momento en la relación con el guionista, proponiendo la compra de los derechos de la obra audiovisual. Aquí empieza una etapa complicada con el guionista. Muchos productores estudian el guion y proponen cambios a la estructura. La relación del productor y el guionista se torna quebradiza. Seger (1999) señala que los produc- 
tores querrán hacer cambios a los guiones, incluso querrán cambiar el género de la historia. Pero esta relación entre productor y guionista se torna conflictiva, ya que el guionista no deseará los cambios en su guion. Tubau (2006) señala:

En las productoras de televisión es muy frecuente que el guionista se enfrente con los directores y productores porque no están dispuestos a hacer el guión que él querría hacer. Al margen de opiniones personales y de quién puede tener más o menos razón (cosa que dependerá de cada caso), un guionista debería saber que generalmente no se le contrata para escribir lo que él quiere, sino lo que desean quienes le pagan (p. 545).

El guionista debe considerar que la obra audiovisual es una obra conjunta de un equipo de muchos profesionales como directores, fotógrafos, luminotécnicos, sonidistas y otras más, y producir la obra poética es la única manera que su historia salga a la luz. "No es una obra literaria y no puede ser respetado como una novela. Es algo que les cuesta muchísimo entender a los guionistas" (Tubau, 2006, p. 573). Por tanto, esta relación conflictiva se resuelve en la medida en que el guionista se adapta al trabajo con el productor y se muestra conciliador y abierto a los cambios. Es un asunto de sobrevivencia.

\section{¿En qué circunstancias concretas se trabaja hoy? ¿Cómo inciden ellas en la re-definición del objeto de una determinada profesión?}

Actualmente, las circunstancias en el trabajo del guionista cambiaron. Circunstancias de mercado y tecnológicas.

Cada día, el mercado de la industria audiovisual es un escenario más competitivo. Antes, los guionistas tardaban más en vender sus guiones. Seger (1999) señala que los guionistas tenían "una primera opción de compra o venta de un guion al cabo de cinco años, o, después de haber escrito cuatro o cinco guiones" (p. 27). Actualmente, la tecnología cambió el panorama. La tecnología hizo que la producción audiovisual se la hiciera de manera más barata. Viñuela (2013) señala que la implementación de la tecnología digital también tuvo repercusión en la industria audiovisual, "el abaratamiento del hardware y el software necesario para este tipo de producciones redujo los costes de producción" (p. 169). Lo que significa que se ampliaron las posibilidades. En ese escenario, el guionista debe comprender y escribir otro tipo de estructuras. Tubau (2011) señala que los guionistas deben probar otras estructuras diferentes a las del cine o de la televisión.

Por otro lado, el guionista se volvió más independiente. En otros tiempos, Tubau (2011) señala que el guionista mandaba su hoja de vida a las productoras o tenía que conseguir una entrevista de un modo perseverante. Ahora el guionista puede producir su mismo material y enseñar en Youtube una escena de su propio guion.

Lo tecnológico, también afectó la praxis de la profesión. Antiguamente, el guionista trabajaba en papel y en una máquina de escribir. Cuando tenía que investigar para un guion lo hacía en una biblioteca y tomaba notas. En la actualidad, el guionista escribe en software especializado como Final Draft o Storylist, o en procesadores de palabras como Word. Cuando hace las investigaciones tiene a disponibilidad una 
gran cantidad de información en la Internet. Esto hace que el guionista realice más rápido su trabajo, y pueda tener a la mano, varias versiones de su obra.

\section{Conclusión}

El guionista sirve a la producción audiovisual a través del guion. Ese guion debe expresar la profunda dicotomía entre lo que subyace en su interior como artista y lo que complace al público, convirtiéndose en un explorador de la condición y la naturaleza humana. Esta búsqueda lo conduce a procurar una verdad poética, a través de la representación de las necesidades humanas. Su relación con el público es cercana y es un intercambio vital. La tecnología apoya su práctica, proveyéndole de software y ampliando las posibilidades de escritura hacia nuevas estructuras. Pero, debe considerar que necesita de un productor. Esta relación con el productor debe ser conciliadora y abierta a los cambios para que su guion se ponga en la pantalla o nuevas pantallas, y la verdad poética que tiene su guion llegue al público.

\section{Bibliografía}

Douglas, P. (2011). Cómo escribir una serie dramática de televisión. Barcelona: Alba Editorial.

Elliot, D y Ozar, D. (2010). Explanation and a Method for the Ethics of Journalism. En Meyers, C. (2010). Oxford Scholarship. (2010, febrero, 16) (pp. 9 a 24). Recuperado 19 de mayo de 2017, a partir de http://www.oxfordscholarship.com/view/10.1093/acprof:oso/9780195370805.001.0001/acprof9780195370805-chapter-1

García-Noblejas, J. (1998). Prólogo del libro de Ronald Tobías - El guión y la trama. Madrid: Ediciones Internacionales Universitarias.

García-Noblejas, J. (2007). Ficción y verdad práctica: entre lo verosimily lo necesario. Poetics \& Christianity. Third Conference: "Mimesis, Truth and Fiction", Rome. Recuperado de http://bib26.pusc.it/csi/conv/09semrf/Noblejas_article2.pdf

Llano, A. (2000). Actualidad del humanismo clásico. Conferencia en la Fundación Universitaria Española, Madrid.

McKee, R. (2005). El guion, sustancia, estructura, estilo y principios de la escrituras de guiones. Barcelona: Alba Editorial.

Ortiz, P. (2007). Waldo Salt, ética, estética y poética: el viaje del guionista (1937-1987). Artigrama, núm. 22, 855-871. Zaragoza: Universidad de Zaragoza.

Seger, L. (1999). Cómo llegar a ser un guionista excelente. Madrid: Ediciones RIALP S.A.6

Tubau, D. (2006). Las paradojas del guionista. Barcelona: Alba Editorial.

Tubau, D. (2011). El guión del siglo XXI. Barcelona: Alba Editorial.

Viñuela, E. (2013). El videoclip del siglo XXI: el consumo musical de la televisión a Internet. En Musiker: cuadernos de música, (20), 167-185. Oviedo: Universidad de Oviedo. 